Final version published in Science \& Society, 75(2), 2011

\title{
The Limits of an Egalitarian Ethos: G.A. Cohen's Critique of Rawlsian Liberalism
}

\author{
By Justin P. Holt
}

\begin{abstract}
G.A. Cohen's critique of the Rawlsian difference principle points out an inconsistency in its presentation. The initial equality decided by the participants in the original position under the veil of ignorance is not preserved by the inequality sanctioned by the difference principle. Cohen shows how the breakdown of the initial equality of the original position prevents the desired results of the Rawlsian system from being realized. Cohen argues that an egalitarian ethos is required within a society for equality preserving economic distributions and Paretosuperior outcomes to occur. Nonetheless, Cohen's analysis of Rawls misses the ultimate cause of inequality, which is the dynamics of capital accumulation. An egalitarian ethos is only possible if there is a socialist mode of production to facilitate its development. Additionally, Cohen's critique of Rawlsian constructivism through an argument for intuitionism does not address the natural-material existence of human beings. This existence must be considered for any advantageous social formation.
\end{abstract}

\section{Introduction}

Over G.A. Cohen's career he was a major figure in the Analytical Marxism movement; his work Karl Marx's Theory of History: A Defense was his seminal contribution. In Defense Cohen argued in favor of many Marxian categories such a historical materialism, class struggle, and base and superstructure distinctions. The work was powerfully argued and, I found, a delight to read and indispensable in the explanation of many Marxian ideas. Since its publication, Cohen questioned, in particular, the cogency the Marxian analytical category of exploitation and thought that Marxism should have more to say about normative matters. But, even though Cohen had a critical stance towards Marxist's methods he argued from a socialist standpoint throughout 
all of his works. His Self-Ownership, Freedom and Equality is such a work where he critiqued Robert Nozick's libertarian political philosophy and argued for socialist societal arrangements. One of his last works, Rescuing Justice and Equality, is a book in this tradition where he provides a systematic critique of Rawls's theory of just distribution and of his constructivist method from a socialist, but not explicitly Marxist, standpoint. ${ }^{1}$

Rescuing is an intricate and pathbreaking philosophic work that will be of immense benefit to scholars who are interested in egalitarianism and socialism. This work is divided into two sections. The first section is an egalitarian critique of Rawlsian arguments for distribution and incentives. The second section is a critique of Rawls' constructivist method and an exposition of Cohen's own philosophic method for the determination of norms, which generally can be called intuitionist. The two sections are presented separately, but Cohen's main intention of this work, that public policy and private intentions have to be in correspondence for just outcomes to obtain, bridges both sections.

Cohen's critique of Rawlsian liberalism finds its origins in Marx's own critique of liberal rights theory developed in On the Jewish Question (Cohen, 2008, 1). Cohen agrees with Marx that a society can never achieve the full development of human abilities when people are treated as equal citizens and unequal private persons. Simply, Cohen thinks that the great weakness of liberalism, with Rawlsian liberalism as it representative type, is that rapacious self-interest maximization can occur along with, and contrary to, the egalitarian intentions of state redistributive policy.

Cohen's critique is centered on Rawls' mechanism for just distribution, which is called the difference principle. This principle allows for inequalities if they are to the benefit of the worst off. The intention of the difference principal will probably appeal to many socialists and social

\footnotetext{
${ }^{1}$ I will call this work Rescuing for the remainder of the article
} 
democrats, as Cohen thinks it does, since gains for the best off are only permitted when the worst off benefit. But, Cohen finds the difference principle to be contrary to the egalitarian impulse of Rawlsian liberalism. Inequalities in compensation are allowed by the difference principle not strictly to render compensation equal when indexed to arduous labor or unpleasant work, but to meet the demands of certain groups, usually in privileged social positions, who desire high pay for their preferred labor tasks or low taxes on their capital and profits. The demands of these privileged groups are contrary to the egalitarian spirit of the difference principle. Cohen's argument against this kind of compensation is that these individuals demand higher pay for an amount of work that could be provided at lower pay with little detriment to themselves. High compensation for those who can demand it from society is not an egalitarian pay differential but self-interest maximizing.

Cohen's critique of constructivism demonstrates his philosophic acumen, and the intuitionist ${ }^{2}$ theory he favors is persuasive, but as I argue below, not ultimately convincing. Cohen shows that norms are not generated by constructivism; rather, he argues that norms are derived from our intuitions. Constructivism can generate rules for social organization but these rules are based on our intuitive principles. This critique has important implications for Rawls method which attempts to ground normative principles, at least for politics, on rationally agreed outcomes.

Cohen's Rescuing is a precise critique of Rawls' difference principle but in the end misses the reason why Rawls makes the mistake of inconsistency when allowing unjust inequality to follow from a commitment of equality. This oversight by Cohen is to leave out the effects capitalist accumulation has upon the promotion of certain activities. The capitalist mode of production will favor and reward activities that extract surplus value. Accordingly, the social climate of

\footnotetext{
${ }^{2}$ The philosophic terminology will be defined when the notions are discussed. Also, I have tried to keep it to a minimum. Intuitionism and constructivism are defined in part III.
} 
capitalism allows and condones the inegalitarian incentives that Cohen brings Rawls to task for. Furthermore, Rawls misidentifies the nature of capitalist accumulation and thinks that a just basic structure will be able to limit and control the dynamics of competition and exploitation. Cohen follows Rawls lead by not considering the incompatibility of egalitarianism and capitalism, at least not in Rescuing. Also, Cohen's argument for intuitionism lacks a proper natural-materialist basis for normative claims. Cohen's attempts to structure egalitarianism under intuitionist principles does not attend to the needs and requirements of humans as physical and historical beings. Thus, Cohen's argument for an intuitionist basis is abstract and unnecessary.

This article will be structured in four parts. The first part will be an overview of Rawls' theory of justice with a focus on the difference principle. The second part will be a consideration of Cohen's various critiques of the Rawlsian difference principle. The third part will be an overview of Cohen's critique of constructivism and a presentation of his intuitionist theory. The fourth part will be my own critique of Cohen's analysis of Rawlsian distributive theory and his theory of intuitionism.

\section{An Overview of Rawls}

Rawls' contribution to political philosophy is monumental and most political philosophy, at least in the English-speaking world, since the publication of $A$ Theory of Justice (which I will call Theory for the rest of the article) has been constructed in light of his accomplishments. There is much to learn from Rawls and if anyone wants to seriously critique liberalism on a philosophic level, Rawls' Theory must be addressed. His work has been widely praised for its philosophic originality and penetrating critique and endorsement of certain economic inequalities. Cohen 
finds that Rawls' critique of inequality is inconsistent as will be shown in the second section. But first we need to understand why Rawls said that certain inequalities should be tolerated.

All roads in Theory lead to Rawls' philosophic social contract method, also called constructivism. ${ }^{3}$ Rawls uses a philosophic device called the original position, which is a hypothetical situation common in the social contract theories of Hobbes and Locke. It is used to derive the rules of social regulation that people would choose under specific conditions. Simply, the conditions that Rawls assumes are: that people are rational (they know what they want and the order they want it), they have no knowledge of their own social position or their preferences and people have no information about the developmental level of the society for which they are choosing. This condition Rawls calls the veil of ignorance (Rawls, 1999, 11-12). ${ }^{4}$ What these conditions are intended to foster are the approximation of being in the position of an unbiased chooser. Being unbiased means that one will not pursue one's own advantage to the unjust detriment of others. This is why Rawls uses the veil of ignorance and the ability to choose rationally as the conditions of the original position. If one can order preferences rationally, but doesn't know what one's own preferences are, then one is in the position of choosing for everyone. As we can see, this hypothetical situation can only generate a preference ordering for a proxy person, which is a stand-in for all people and not the preference for an individual person with their personality intact. If one has to choose from the perspective of the veil of ignorance, how does one choose when one doesn't know one's social position or what one's abilities are?

\footnotetext{
${ }^{3}$ Cohen finds that Rawls' constructivism is not a social contract method (see page 337 of Rescuing Justice and Equality). This is why I will call Rawls' method constructivism and not social contract nor contractarian. I will not consider why Cohen thinks Rawls' method is not contractarian in this article.

${ }^{4}$ Many authors have criticized Rawls' use of the original position and the veil of ignorance as devices. Thomas Nagel (1973), Michael Sandel (1982), and Michael Walzer (1983) all question whether it is possible to make any meaningful decisions of society without a prior conception of the good. In short, can we know what society we want when we have no desire for any such society? In his later work Rawls (1993, Lecture V) does explicit state that people do have some notions of the good within the original position, which appears to be a revision of his position in Theory. Jürgen Habermas (1995) remained unconvinced by Rawls' revisions; he still found a sufficient conception of the good to be excluded by the veil of ignorance.
} 
Simply put, you are choosing as if you are either an affluent person with rare and desirable skills or a poor person who has no skills. Or you are choosing as if you are young and healthy or old and infirm, or a man or a woman, or black or white, or a member of a majority religion or a despised minority sect, and so on.

With such a lack of information, but with the knowledge that inequalities can and do occur without state rectification and prevention, how does one choose? Rawls thinks that without information of who one is and what kind of society one will enter into one cannot generate any probabilities for one's prospects. One thus chooses under the conditions of uncertainty. If this is the case, then the only strategy one can use to generate social rules of regulation is called maximin, which is the maximization of the least advantaged (minimal) social position (Rawls, 1999, 132).

So, if one is under the veil of ignorance and one uses the maximin strategy, what rules (what Rawls calls principles of justice) will one choose? Rawls finds that people would choose to adopt two principles of justice: (1) equal basic liberties for all people; and (2) "social and economic inequalities are to be arranged so they are both (a) reasonably expected to be to everyone's advantage, and (b) attached to position and offices open to all" (Rawls, 1999, 53). As we can see, inequalities are tolerated in resource distribution, but not tolerated for political liberties. ${ }^{5}$ Rawls thinks that people would choose equality in political liberties and inequality in resources because both are to people's advantage. Also, political liberties cannot be unequal since matters of conscience are the most important to people (Rawls, 1999, 131). ${ }^{6}$ When it comes to the second

\footnotetext{
${ }^{5}$ Norman Daniels finds this discrepancy cannot be maintained since liberty is not as valuable if one has insufficient resources. See Daniels' "Equal Liberty and Unequal Worth of Liberty." Rawls (1993, 324-331) attempts to counter Daniels critique by maintaining what he calls the fair value of liberties. Rawls only brings up the separation of political power from social and economic power as the solution. But, Daniels whole critique is that these guarantees are insufficient within a society that allows widespread private property ownership.

${ }^{6}$ One of the most penetrating critiques of the two principles has been offered by H.L.A. Hart (1973). He argues that the selection of the two principles is not ordered in the way that Rawls thinks they are. He finds that people may rationally select economic gains over personal liberties. Rawls, in his later work, develops a refutation of Hart's
} 
principle, Rawls finds that equality would be the starting point when it comes to the distribution of resources and positions in society (Rawls, 1999, 55). Inequality will only occur if it is to the benefit of the worst off: "The intuitive idea is that the social order is not to establish and secure the more attractive prospects of those better off unless doing so is to the advantage of those less fortunate" (Rawls, 1999, 65). Rawls embraces equality in the control over economic resources and will only agree to inequalities if they are to the benefit of the worst off. This distributive rule is the difference principle. ${ }^{7}$

In Table 1 we have three distributive situations demonstrating equal distribution (A) and two situations of economic inequality (B and C). Situation $\mathrm{A}$ is of initial equality where our two classes have equal shares of economic resources. The difference principle would permit movement only from situation A to situation $\mathrm{B}$ since situation $\mathrm{C}$ does not improve the resource shares of the worst off.

Table 1

\begin{tabular}{|l|c|c|c|c|}
\hline \multicolumn{1}{|c|}{ Situation } & $\begin{array}{c}\text { Resource shares for } \\
\text { the worst off }\end{array}$ & $\begin{array}{c}\text { Resource shares for } \\
\text { the best off }\end{array}$ & $\begin{array}{c}\text { Total societal wide } \\
\text { resource shares }\end{array}$ & $\begin{array}{c}\text { Societal wide } \\
\text { resource averages }\end{array}$ \\
\hline A: Equality & 5 & 5 & 10 & 5 \\
\hline $\begin{array}{l}\text { B: Inequality permitted } \\
\text { by the difference } \\
\text { principle }\end{array}$ & 6 & 7 & 13 & 6.5 \\
\hline $\begin{array}{l}\text { C: Inequality not } \\
\text { permitted by the } \\
\text { difference principle }\end{array}$ & 4 & 10 & 14 & 7.5 \\
\hline
\end{tabular}

Table 1 has been developed by the author.

critique based on a conception of the person that prizes the priority of their conscience; Rawls argues that this is a more realistic understanding of an agent within the original position (1993, Lecture VIII). This clarification allows Rawls, he thinks, to avoid the possibility of a rational person with a preference set that orders economic gains before personal liberties as a sufficient benchmark for all persons within the original position.

${ }^{7}$ Cohen major point of critique is the reasoning of the difference principle, which will be discussed in the next section. Also of note are the critiques by Robert Nozick (1974, chapter 7), Ronald Dworkin (1981), and Paul Gomberg (2007). 
Movement away from inequality is only permitted if the resources enjoyed by the worst off improve (or stay the same according to some versions of the difference principle, see Cohen, 2008, 157).

Rawls' main opponent in Theory is utilitarianism. Rawls' criticism of utilitarianism is that beneficial determinations according to various utilitarianisms will permit outcomes that provide the greatest gains for the entirety of society, whether considered as total or average gains for society, even if certain peoples' resource allotments decrease (Rawls, 19 and 160). Utilitarian reasoning, of both total sum and average varieties, will prefer situation C over B since the total gain for society or the average gain for all are the greatest. But, situation $\mathrm{C}$ entails losses for the worst off even though the total and average gains for the entire society are the greatest of all three situations. The Rawlsian difference principle thus tries to protect the prospects of the most vulnerable by attending to their individual positions in society. ${ }^{8}$

If we return to the perspective of the original position, under the veil of ignorance, why would one choose situation $\mathrm{B}$ over $\mathrm{A}$ or $\mathrm{C}$ ? If one is using the maximin strategy when selecting principles of justice, and the three distributive situations help to analyze what their choice should be, only choice B maximizes the worst off position. Since one does not know what one's position in society will be, B is a safer choice than C. Rawls considers people to be risk averse where there is uncertainty (Rawls, 1999, 133).

Rawls' commitment to minimizing economic inequality goes beyond the difference principle. He also thinks that large wealth holdings should not be inherited (Rawls, 1999, xv and 245),

\footnotetext{
${ }^{8}$ Amaryta Sen's $(1980,1992,1999)$ critique of the difference principle is not with the distributive rule, as much as with what is being redistributed and who is identified as the worst off. Rawls thinks that basic primary goods (such as income, health care, and self-respect) are what should be redistributed (Rawls, 1999, 79). He thinks the least advantaged social class (such as unskilled workers) is who should be identified as worst off (Rawls, 1999, 84). Rather, Sen argues for capabilities (such as being capable to learn, work, be free to voice one opinion, etc.) as what should be redistributed and a more nuanced and culturally specific consideration of who are the worst off (such as women in India or Blacks in the United States).
} 
income transfers should be used to maintain basic living standards and full employment is a responsibility of the state (Rawls, 1999, 244). Rawls' overall consideration of what people would choose in an unbiased situation is strong protections against the accumulation of wealth and multiple resources for the maintenance of living standards. Rawls also finds that the principle of justice chosen in the original position can apply to either property-owning democracy (his term for regulated capitalism) or socialism (Rawls, 1999, 242). Rawls' intentions are to protect the economically vulnerable and permit gains for the well off and privileged only when they benefit the worst off.

\section{II: G.A. Cohen's Critique of the Rawlsian Difference Principle}

As we have seen the difference principle will only deviate from an equal distribution of resources when the worst off in society will gain (or at least not lose). Cohen does not disagree with the difference principle in general; he thinks that it retains an egalitarian impulse in its abstract formulation. But, Cohen finds that there is a flaw in the logic of the difference principle when it is applied to particular kinds of incentives. Specifically, he thinks that the difference principle is not a justification for a just distribution when the incentives it permits are solely for encouraging people to perform jobs they enjoy. This means that these jobs do not require remuneration to compensate for the arduous expenditure of energy or the displeasing nature of the work. Cohen does say that such unjust distribution may be required to assist the worst off when drafting policy for a populace that does not have an egalitarian ethos (Cohen, 2008, 83). Cohen's criticism of incentives that people wish to have, but genuinely do not need, is also the basis for his critique of the difference principle according to Pareto-improvements, the distinction between the public and the private, and freedom of occupational choice. 
Cohen's critique of non-egalitarian incentives is concerned with the motives that cause the deviation from the equal distribution of resources, which is the starting point for the Rawlsian difference principle. As we saw in Table 1, movement away from equality of distribution can only be considered just when the worst off benefit, since that is what people would choose as their definition of justice in the original position. But, this condoning of inequality does not consider the reasons why this inequality occurs. Broadly, Cohen thinks that inequalities can be grouped into two cases, one which is egalitarian and one which in inegalitarian (Cohen, 2008, 56-58). The egalitarian case permits inequality in resource distribution to offset the arduousness or undesirability of the labor performed. The unequal pay that these laborers receive is equality preserving; it compensates them for their exertion beyond the norm or the displeasing nature of their work. The inegalitarian case is when certain individuals perform labor that they prefer and is not arduous. The only reason they receive unequal pay is because they prefer to receive high compensation. They are perfectly able and willing to perform the tasks they are qualified for but would rather do so only for a higher salary or higher investment return.

The whole reason Cohen is concerned with this inegalitarian incentive is that he finds it to be a typical argument for the high compensation of certain jobs or high remuneration for investments (such as for entrepreneurs, chief executives, rentiers, and financiers). The incentives argument for these people is phrased in the terminology of the difference principle. If we do not pay these people high salaries or keep their taxes low then they will not produce as much as they could at their high pay or low tax rate and this will be to the detriment of the worst off (Cohen, 2008, 35). These people are not being compensated for their difficult or unpleasant tasks, they are simply saying: 'if you wish us to work to our potential we want more money, even though we could perform at our potential without the additional compensation.' To stress the difference 
between this case and the case of the arduous or displeasing labor, those who perform these kinds of labor would say: 'if you wish us to perform these task we need to have additional money to compensate for the difficulty of the task.' Simply put, inegalitarian incentives are not required for people to perform their tasks; they prefer to perform normally stressful and normally difficult labor at a higher than necessary compensation rate.

Cohen finds this derivation from equality incommensurate with the impulse of the difference principle because it takes equality as its starting point. Since Rawls endorses all movement away from equality that benefits the worst off, he does not attend to the starting point impulse being preserved in the transformation. ${ }^{9}$ This means that the difference principle, in the manner Rawls interpreted it, is inconsistently applied when the reasons for differential incentives are not examined. If the difference principle had a starting point that was one of inequality, but would only condone changes in the distribution which benefited, or at least left unchanged, the condition of the worst off, Cohen's critique would be moot. But, why people would decide, under the veil of ignorance, to select an unequal starting point in the original position when they are implementing a maximin strategy is difficult to comprehend. The perspective of the original position makes it difficult to argue for why people would allow such differentials when they are in a situation to prevent them from occurring. Additionally, if you don't know what your abilities will be would you readily accept the notion of paying people more for labor that they can perform at a normal rate? Seemingly no. But, one would be willing to use incentives to encourage people to perform necessary labor which is difficult and unappealing since it would benefit the worst off, for example digging deep water tunnels, garbage removal, and sewer repair.

\footnotetext{
${ }^{9}$ Rawls would not allow gains that were due to unjust actions such as slavery, assault, theft, etc. These actions would be forbidden by the first principle of justice.
} 
Cohen extends his critique of the difference principle to include a critique of Paretoimprovements due to inegalitarian incentive payments (Cohen, 2008, 79 and chapter 2). In Table 2 there are three distributive situations. Situation D is an initial situation of equality and situations E and F are Pareto-improvements.

Table 2

\begin{tabular}{|l|c|c|c|}
\hline \multicolumn{1}{|c|}{ Situation } & $\begin{array}{c}\text { Resource shares for } \\
\text { the worst off }\end{array}$ & $\begin{array}{c}\text { Resource shares for } \\
\text { the best off }\end{array}$ & $\begin{array}{c}\text { Total resources of } \\
\text { society }\end{array}$ \\
\hline D: Initial Equality & 5 & 5 & 10 \\
\hline $\begin{array}{l}\text { E: Unequal Pareto- } \\
\text { Improvement }\end{array}$ & 6 & 7 & 13 \\
\hline $\begin{array}{l}\text { F: Equal Pareto- } \\
\text { Improvement }\end{array}$ & 6.5 & 6.5 & 13 \\
\hline
\end{tabular}

Table 2 has been developed by the author.

Cohen finds that if situations $\mathrm{E}$ and $\mathrm{F}$ are Pareto-improvements, situation $\mathrm{E}$ demonstrates nonegalitarian incentive payments (that is incentives for work which is not difficult or displeasing), and situation F demonstrates a Pareto-improvement which is equality preserving. Both situations have the same total resource gain for society, only the distribution of the gains is different. With this kind of example Cohen wishes to show that inegalitarian incentive payments are not strictly necessary for Pareto-improvements when the incentives are only for appeasing the preferences of certain groups. Cohen summarizes his consideration of egalitarian Pareto-improvements as such:

The set of possible social worlds will, moreover, usually contain a Pareto-optimal equal distribution that is also Pareto-superior to the initial equality, and that must be preferred to the recommended unequal distribution, on pain of abandoning the rationale of the initial equality. (Cohen, 2008, 90).

Cohen's interest in pointing out why incentives are needed in certain situations stems from his approval of Marx's critique of liberal rights theory developed in On The Jewish Question (Cohen, 2008, 1). Marx considers the liberal theory of rights to divide people into two: public 
citizens and private persons. Liberalism provides equality for public citizens but does not do so for private persons. Public citizens are conceived of in the abstract, as equal before the law, whereas, private persons are denied the means for exercising their liberty, which is access to the means of production. Moreover, Cohen finds Marx's critique to hold for modern day liberalism, including Rawlsian liberalism. This division between public and private persons is a deep rift in liberal political philosophy that is demonstrated by its condoning of inegalitarian incentive payments that are not really to the benefit of the worst off, since the best off don't truly require compensation for their labor. The deep rift that Cohen, following Marx's lead, identifies in liberalism only requires that people submit to the public legal enforcement of egalitarianism. They do not have to accept the egalitarian ethos as a personal norm.

This division between public egalitarian citizens and private inegalitarian personal gain maximizing behavior prevents a society from achieving the best outcomes for the worst off as evident in Table 2. If people commit their private lives to egalitarianism then the rapacious outcomes of situation $\mathrm{E}$ can be avoided and the gains available in situation F can be achieved. As Marx argued, if society is divided between public equality and private inequality people's lives will not be as full as they can be. Cohen emphasizes an egalitarian ethos as the missing element of the liberal egalitarianism of Rawls. Considering this point from the perspective of the original position we can see that people, under conditions of uncertainty, would understand how endorsing an egalitarian ethos would be the maximin outcome if the choices were between situations $\mathrm{E}$ and $\mathrm{F}$. Indeed, once one has realized that a starting point of equality would be maximin it is evident that possible Pareto-improvements that preserve this equality would be prized. 
Finally, Cohen wants to discuss the freedom to choose one's occupation under the constraints of egalitarianism. As has been shown in Table 2, people who have an egalitarian ethos should choose to perform labor that they prefer for less compensation as a way of improving the situation of the worst off, even though they could protest and threaten to not work as hard as they could, thus forestalling a Pareto-improvement and keeping society in situation D (Cohen, 2008, 58). Cohen wants to consider if the egalitarian demand to accept less pay to assist the worst off also applies to the selection of jobs. Cohen's consideration only applies to jobs people prefer to do. If they take a job they do not prefer they are due additional compensation, which is congruent with extra pay for people who perform arduous or unpleasant tasks (Cohen, 2008, 211).

Cohen in interested in confronting what he considers a trilemma between equality, Paretoimprovements, and freedom of occupational choice (Cohen, 2008, chapter 5). The examples above have demonstrated a dilemma between equality and Pareto-improvements. Traditionally this dilemma considered a tradeoff between equality and Pareto-improvements as the sole outcome because the only motivation considered possible has been inegalitarian personal gain maximization. But, Cohen has demonstrated that one can have Pareto-improvements and equality if people are motivated by an egalitarian ethos. The trilemma would involve trade-offs between either egalitarian Pareto-improvements that sacrifice occupational choice, egalitarian outcomes that preserve occupational choice and sacrifice Pareto-improvements, or Paretoimprovements that preserve occupational choice but sacrifice egalitarian outcomes. Cohen thinks the traditional understanding of the trilemma requires one of the three desired outcomes to be sacrificed.

Not surprisingly, Cohen again wants to show that an egalitarian ethos can promote people to choose a job they prefer while also preserving egalitarian Pareto-improvements. He shows how 
this is possible by critiquing Amartya Sen's famous example of a Paretian liberal (Cohen, 2008, 187). The Paretian liberal example demonstrates that when people cannot coordinate their optimal preferences an agreed outcome will be sub-optimal. Cohen thinks that Sen's example is lucid but he thinks that, "within the structures of possibility that liberal rights create, you cannot both be loyal to certain values and get what you would prefer (not all things considered, but) if you prescinded from those particular values (Cohen, 2008, 188)." Sen's reading of the trilemma would be that no Pareto-optimal outcome is possible when people retain their preferences. Whereas, Cohen finds that we can have Pareto-optimal outcomes that are egalitarian while preserving our preferences if the choice is between a set of jobs we prefer. If one is motivated by an egalitarian ethos one can select a preferred job at an egalitarian pay rate which is Paretooptimal (Cohen, 2008, 189-190).

Of course, one may have a greater preference to perform another job, or the chosen job at a higher pay rate. Cohen acknowledges this, but his solution preserves occupational choice because one does prefer the job chosen, one just prefers another job more. Cohen's reasoning is in alignment with Rawls' original position and social contract reasoning in general, where the keynote is that people concede certain actions for the benefits of social organization. ${ }^{10}$ In the Rawlsian original position people seek stability, the gains made possible by social union, and the fulfillment of their self-respect (Rawls, 1999, 14, 372, and 491). The assumptions of Rawls' political model are thus followed by Cohen who is only taking Rawls at his word that people wish to live in a well-ordered society where they can develop a sense of justice amongst citizens (Rawls, 1999, 498). And, I would say, that Cohen is only adhering to the standards of western political philosophy as this passage from Aristotle shows:

\footnotetext{
${ }^{10}$ Such reasoning is part of the social contract tradition: see Hobbes (1994, chapter 14) and Locke (2003, 137).
} 
Concord appears to be political friendship, as the phrase is used; for it is concerned with matters of expediency and those which affect our whole life. Such concord exists in good men, for these have the same thoughts in themselves as well as in relation to one another, having the same things in mind so to speak; for the things wished by such men are constant and do not ebb and flow like the water in the strait of Euripus, and they also wish what is just and expedient, and these are the things they commonly aim at. (Aristotle, 1984, 170).

Concord, Rawls' sense of justice, Cohen's egalitarian ethos, or Marx's higher stage communism, are all names for the same consideration, which is that the best form of social organization can only exist if people are committed to its success and well-being. Cohen is only reminding Rawlsians, and liberals in general, what they supposedly believe in and what they have all learned already.

Cohen has demonstrated in great detail and with great insight that liberal political philosophy has a flawed understanding of distribution if inequalities are considered just if they are to appease rapacious groups. Simply, Cohen has critiqued liberals on their own terms, with their own game, and has demonstrated that their assumptions do not lead them where they wish to go. Nonetheless, I think that for all of the strengths in Cohen's critique of Rawls' difference principle he leaves out the important Marxist critique of capitalism in his appraisal of inequalities. I will return to these matters in the final section after I outline Cohen's analysis of constructivism.

\section{III: G.A. Cohen's Critique of Constructivism}

A brief description of terminology is necessary before I move into the details of Cohen's critique of Rawlsian constructivism using of his own intuitionist method. ${ }^{11}$ Constructivism is a method for the selection of norms according to what people would choose as these norms. This is exactly what the original position is meant to do, help people decide the set of norms they wish to live

\footnotetext{
${ }^{11}$ Cohen also calls the method he employs radical pluralist and he also declares himself a "partisan" of standard deontology (Cohen, 2008, 4).
} 
by. Intuitionism is the selection of norms according to our own intuitive judgments. As Cohen describes it:

[W]e determine the principles that we are willing to endorse through an investigation of individual normative judgments on particular cases, and while we allow that principles that are extensively supported by a wide rage of individual judgments can override outlier judgments that contradict those principles, individual judgments retain a certain sovereignty. (Cohen, 2008, 4.)

Cohen's critique of constructivism posits that the selection of principles of justice in the original position is not the ultimate grounding for normative determinations. Rather, Cohen finds that what is decided in the original position are rules of societal regulation that are based on fundamental normative principles that precede and shape our choices of these rules within the original position. Also, Cohen thinks Rawls' claim that all normative principles are based on facts is incorrect. Rather, Cohen argues that all rules of regulation and all normative principles that are fact sensitive are ultimately grounded upon further normative principles that are fact insensitive. In a nutshell, Cohen thinks that constructivism can provide rules for social regulation but these rules are based on fundamental normative principles that are derived from our own individual intuitive judgments that are not demonstrated by facts (Cohen, 2008, 275).

Cohen does agree that many principles $P$ that people invoke will be in light of a fact $F$. But, if the invoked principles are examined people will eventually arrive at a principle which is fact insensitive $P I$ (Cohen, 2008, 234). I have paraphrased an example that Cohen provides:

$R P$ : We should keep our promises.

$R F$ : Because only when promises are kept can people successfully pursue their projects. RP1: We should help people pursue their projects. (Cohen, 2008, 234).

Cohen finds that $R P 1$ is fact insensitive, which means that there is no fact that supports or demonstrates $R P 1$. Principle $R P$ is fact sensitive and is demonstrated by the fact $R F$. Cohen does 
not offer a multitude of examples but the general idea is clear: our normative judgments develop fundamental principles which ultimately have no factual basis. This means that the way we should live our lives and what we should strive for is determined not by our natural and social conditions but by our deepest intuitive convictions. Social conditions do shape which rules of regulation are rational to select, but these rules of regulation are only just if they are in agreement with our intuitive fundamental principles. ${ }^{12}$

Cohen uses his intuitionist method to show that the constructivist original position does not generate fundamental normative principles. The original position only generates rules of regulation, which are based on intuitive fundamental principles. The difference principle is not a fundamental normative principle; it is rule of regulation. As Cohen describes this relationship:

One strategic fact is that there exist goods with which people need to be provided to pursue their life plans. Those help to yield the general conception, together with the unstated fact-insensitive principle that, so far as possible, everyone should be equipped with what, if anything, she need to pursue her life plan, if she has one, which in turn rests on the principle that one ought to promote fulfilling lives.

(Cohen, 2008, 293).

The difference principle's notion of providing social integration via the just distribution of resources is not a rational notion demonstrated by facts. Instead, Cohen insists that why people want to facilitate the lives of others is because they have a deeply held conviction. This means that the reason why people implement the difference principle is because people want to promote fulfilling lives. Rawls has shown that if the conditions of the original position shift to allow for more personal knowledge in the decision-making process people will select forms of utilitarian distribution (Rawls, 1999, 142). But, the fundamental distributive principle will be, no matter what the conditions are for the selection of the rules of regulation, that people should promote

\footnotetext{
${ }^{12}$ We can, of course, select rational rules of regulation that are unjust. Cohen would think it would be foolish not to do so in cases where just outcomes are impossible (Cohen, 2008, 82). That is we enter into a modus vivendi with others to have a functioning but unjust society. This would be the best of possible circumstances, the other option being civil war.
} 
fulfilling lives. Thus, fundamental normative principles hold even if certain facts do not obtain, such as the veil of ignorance conditions.

Cohen's intuitionist method demonstrates that constructivism does not determine fundamental normative principles. There is something that precedes the selection of rules of regulation. But, I don't think they are intuitively derived fundamental normative principles. Rather, I have the suspicion that humans' natural-material capacities and requirements may be what ultimately forms the basis by which we select rules of regulation.

\section{IV: A Materialist Critique of Cohen and Rawls}

In this section I will argue against Cohen on two points. First, I will argue that Cohen leaves out the Marxian analysis of inequality to the determent of his critique of the Rawlsian difference principle. Second I will argue that the basis Cohen's intuitionism and Rawlsian constructivism is built upon is ultimately the natural-materialist structure of human existence, and not intuitive principles or the rational choices that people make.

Cohen's critique of incentives that are not equality preserving does not consider a fundamental factor of why such inequalities are possible: that the social relations of any mode of production favor certain behaviors that coincide with the accumulation patterns indicative of that particular mode of production. For example, within feudalism behaviors that facilitate feudal accumulation patterns, appropriation of an agriculture surplus, are favored; whereas, within capitalism behaviors that facilitate capitalist accumulation patterns, extraction of surplus value, are favored. Capitalism arose out of the possibility of surplus value extraction under feudal conditions and within its mode of production capitalism is structured around this extraction. Thus, actions that facilitate surplus value extraction are intrinsic to the operation of capitalism 
and are not an extraneous occurrence. Inequalities that allow people to capture a greater share of an extracted surplus are sanctioned by the ethos of capitalism. The egalitarian ethos that Cohen finds absent in Rawls' construction of the difference principle is due to it being in conflict with capitalism's ethos of exploitation and alienation. Simply put, we can't expect an ethos of egalitarianism to arise when the fundamental social relations do not prize or reward such an ethos. $^{13}$

Cohen's critique of Rawlsian distributive justice misses a problem that Rawls thinks he can avoid: that the inequalities of capitalism are due to its internal dynamics. ${ }^{14}$ Rawls identifies the inequality of capitalism as not intrinsic to it, but only a byproduct of the absence of the difference principle, or another just distributive principle. Capitalism will limit inequality and exploitation if the difference principle and other just institutions are in effect (Rawls, 1999, 247248). This means if a just basic structure is in place people will desire that others are not exploited. But, can such an outcome be possible when capitalist competition obtains? Even if people don't wish to exploit others, the demands of competition require capitalist to exploit workers to survive as capitalists. Rawls essentially wants competition without the negative results. The problems countries with substantial welfare systems have had in the past thirty years resisting the demands of capital should make one reconsider the plausibility of Rawls' claim. ${ }^{15}$

Cohen's endorsement of an egalitarian ethos at first appears that it could be a critique of Rawls neutrality on how different modes of production favor certain distributive outcomes. But, Cohen's egalitarian ethos is only a critique of Rawls reasoning, and not a critique of the pass that

\footnotetext{
${ }^{13}$ Richard Miller (1974) has reached a similar conclusion.

${ }^{14}$ Rawls does think that a just society can be capitalist or socialist (Rawls, 1999, 235-242). Rawls thinks that a county's "traditions, institutions and social forces" determine whether it is socialist or capitalist (Rawls, 1999, 242). The selection of economic systems is not a matter for justice, or, more to the point, it is not a factor in the development of the well being of people. Rather, what causes a country to have advantageous outcomes is a just basic structure and not its mode of production. See Holt (2009b) for a more detailed presentation.

${ }^{15}$ On the attempted rollback of welfare systems see: Herrera (2006) and Stephens (1996). On the limits of socialdemocratic control over capital see: Esping-Andersen (1999, 184).
} 
Rawls gives to the effects of capitalist accumulation dynamics. Cohen does mention that people may become habituated to the distributive outcomes of their mode of production (Cohen, 2008, 50); they thus find their wages or capital income to be a natural distributive pattern. ${ }^{16}$ His critique is to point out that Rawls is not consistent in his appraisal of equality. Cohen does not consider that capitalist accumulation dynamics are unable to foster an egalitarian ethos, even though he has endorsed a similar point elsewhere (Cohen, 2000, 304; Cohen, 1995, chapter 1). Cohen's critique of Rawls' inconsistent consideration of equality is right but misses the basic flaws of Rawls' political economy where the dynamics of capitalist accumulation can be harnessed without detrimental effects. Rawls' thinks that capital can be rendered neutral as a lever of development. Cohen's endorsement of an egalitarian ethos leaves out the societal basis for the fostering of such as ethos.

Cohen thus goes the route of critiquing Rawls on inconsistency concerning equality, but why not go the route of demonstrating the impossibility of egalitarianism within capitalism and then examine the distinct problems of incentives faced by a developing socialist society? True Cohen is worried about socialists being swayed by the egalitarian impulse of the difference principle, but socialists already consider capitalism incapable of providing non-exploitive outcomes. This is why they are socialists and not liberals. The audience that can then be best affected by Cohen's critique are liberals. He backs them into a corner where they must decide between equality or inequality. The option of having an inequality that both lifts all boats and maintains the egalitarian ethos originally agreed to, is ruled out by Cohen's critique. The difference principle turns out to be, at its root, a simplistic invisible hand story once again. In short, Cohen is right that the egalitarian ethos must follow from the initial equality decided as maximin in the original

\footnotetext{
${ }^{16}$ Marx's discuss this phenomenon in Marx (1976a, 680).
} 
position, but his critique leaves out the determination that capitalism is not an adequate mode of production to foster egalitarianism.

The incompatibility of capitalism and egalitarianism brings capitalism as a maximin solution into doubt. If the parties under the veil of ignorance are seeking to provide the most advantageous situation for those with the lowest expectations then socialism is the maximin solution. This is the case because the following aspect of socialism (there are many others in addition): 1) the means of production cannot be alienated from the populace, 2) remuneration decisions are a collective matter, 3) investment cannot be withheld by private interests, and 4) egalitarianism can be considered intrinsic to the production, accumulation, and distribution dynamics of the socialist productive mode. These aspects of socialism are maximin compared to capitalism, which is contrary to all of them. Rawls' primary interest of having a society that is not divided in its interests and finds its social life to be a good is the spirit that drives Cohen's emphasis of an egalitarian ethos. But, people are innately divided within capitalism due to its core organizing dynamic of surplus value extraction through exploitation. Parties under the veil of ignorance find egalitarianism to be maximin, and accordingly they would also find socialism to be so also.

Now onto the second point, I find that the basis that both Cohen's intuitionism and Rawls' constructivism is built upon is ultimately the natural-materialist structure of human existence, and not intuitive principles or the rational choices that people make. Fundamental normative principles are demonstrated by humans' natural-material existence which takes into account our social nature and our ability to materially shape our environment. I think that the fundamental normative principles that Cohen finds lying beneath social rules of regulation are fact sensitive to humans' natural-material existence. Also, the rules that Rawls derives from the original position 
are not based on intuitively derived fundamental normative principles as Cohen says, but are, in actuality based on the natural-material existence of human beings. This means that humans' natural-material conditions must be attended to in the construction of any form of social organization. Accordingly, humans' natural-material existence is a set of facts that fundamental principles and rules of social regulation must be sensitive to.

In order to elucidate what humans' natural-material existence is and how it provides a basis for normative principles and/or rules of social regulation I will draw on passages from Marx and Engels that have formed the groundwork of my considerations. ${ }^{17}$ First, a long passage from The

\section{German Ideology:}

The premises from which we begin are not arbitrary ones, not dogmas, but real premises from which abstraction can only be make in the imagination. They are the real individuals, their activity and the material conditions of their life, both those which they find already existing and those produced by their activity. These premises can thus be verified in a purely empirical way.

The first premise of all human history is, of course, the existence of living human individuals. Thus the fist fact to be established is the physical organization of these individuals and their consequent relation to the rest of nature. Of course, we cannot here go either into the actual physical nature of man, or into the natural conditions in which man finds himself - geological, oro-hydrographical, climatic and so on. All historical writing must set out from these natural bases and their modification in the course of history through the action of men.

Men can be distinguished from animals by consciousness, by religion or anything else you like. They themselves begin to distinguish themselves from animals as soon as they begin to produce their means of subsistence, a step which is conditioned by their physical organization. By producing their means of subsistence men are indirectly producing their material life. (Marx and Engels, 1976, 31.)

And years later, in Results of the Immediate Process of Production, Marx comments:

Man can only live by producing his own means of subsistence, and he can produce these only if he is in possession of the means of production, of the material conditions of labour. It is obvious from the very outset that the worker who is denuded of the means of production is thereby deprived of the means of subsistence, just as conversely, a man deprived of the means of subsistence is in no position to create the means of production. (Marx, 1976, 1003.)

\footnotetext{
${ }^{17}$ I have argued for a similar and more detailed presentation elsewhere, Holt (2009a).
} 
Humans' natural-material conditions are the ground which all human action, desirable or undesirable, stems from. When we consider how human organization should be arranged we need to understand what humans are and what they need as natural-material creatures. Marx and Engels present a set of facts about human existence that form the groundwork which one can develop rules of social organization. The above passages, I think, provides this set of facts:

$H F 1$. Humans are natural creatures that have certain physical requirements.

$H F 2$. Humans have the natural ability to shape their environment.

HF3. Human social organization is shaped by their physical requirements and their natural ability to manipulate their environment. (This point is reiterated by Marx, 1973, 83).

HF4. Human social organization further shapes humans' ability to manipulate their environment. HF5: Types of human social organization can inhibit the satisfaction of humans' physical requirements and can also inhibit humans' ability to manipulate their environments.

These facts must be taken into account when formulating principles of social organization because they are the foundation of humans' natural-material existence. Any sound principles of social organization have to take the facts of humans' natural-material existence as their basis. Otherwise, the principles of social organization would be, at best, incoherent, or at worst, destructive to human life.

A set of principles that can be formulated from these facts:

HP1: People should have their physical requirements met: demonstrated by $H F 1$.

HP2: People should be able to manipulate their environment: demonstrated by $H F 2$.

HP3: Social organization should facilitate the satisfaction of physical requirements and the development of people's abilities: demonstrated by $H F 3$ and $H F 4$.

HP4: Types of social organization that do not sufficiently satisfy people's physical requirements or sufficiently development their abilities should not be used: demonstrated by HF5.

We can, I think, develop a set of normative principles from a set of facts about humans' naturalmaterial existence. For example, if we look at what Cohen thinks is a fact-insensitive principle for the difference principle, which I will call $C P 1$, “one ought to promote fulfilling lives," I think that $C P 1$ can be demonstrated by facts $H F 1$ through $H F 5$ because fulfilling lives are 
synonymous with people having their physical requirements met, being able to manipulate their environments, and living in society that does not inhibit these requirements and manipulations. If I am correct, the fundamental principle $C P I$ that serves as the basis for distributive rules of regulation is fact-sensitive.

Cohen, I believe, would reply by saying, 'all well and good, but the principles you have derived are actually based on principles that are fact-insensitive if you examine their foundation.' This is a possibility. We can reach principles that are indeed fact-insensitive, which could be the foundation for the fact sensitive principles $H P$. But, the fact-insensitive principles we reach are abstract when considered in light of the facts of humans' natural-material existence. I think some principles of this type are:

$X P 1$ : Humans should be alive.

$X P 2$ : Humans should be able to breathe.

These $X P$ principles are fact-insensitive. But, their fact-insensitivity is pointless. It is unnecessary to even recommend them as principles because they tell us what is obvious from the set of $H F$ facts listed above. If humans' natural-material existence is a given for most normative considerations (see the following paragraph), why then should we retreat to fact-insensitive principles that tell us what we have to deal with already as facts? I think there is no reason. $X P$ type fact-insensitive principles are possible ethical statements if we consider ethical statements as being analytically separated from political-social statements. We can discuss humans in this abstract manner, but this discussion is purely scholastic and does not attend to facts that must obtain for humans to have a materially stable social arrangement. I think that Cohen's considerations are correct that all principles are based on fact-insensitive principles (of the small set of $X P$ types principles), but only in an analytical sense that does not add 
meaningfully to our normative understanding. After we accept the assumption that humans should be alive we must attended to the facts of their natural-material existence which we shall have to base normative principles upon. ${ }^{18}$

Rawls does consider a similar notion about principles/rules being grounded on the facts of humans' natural-material existence. He calls the account of what humans require the "thin theory of the good (Rawls, 354)." The thin theory of the good establishes a set of facts about the resources required for humans to exist at an optimal level indexed to the historical level of productive development. This thin theory allows people to construct principles of justice:

This account of the good I call the thin theory: its purpose is to secure the premises about primary goods required to arrive at the principles of justice. Once this theory is worked out and the primary goods accounted for, we are free to use the principles of justice in the further development of what I shall call the full theory of the good. (Rawls, 1999, 348).

Broadly, I am in agreement with Rawls concerning the factual basis for normative political principles. But, as discussed above, Rawls does not attend to the serious limitations capitalism imposes on the satisfaction of physical requirements and the development of abilities. Simply, I think that Rawls' allowance of regulated capitalism violates principle HP4 listed above. Once again, why would one, when in the original position under the veil of ignorance, with knowledge of the history of capital accumulation, inequality, and crisis, select property-owning democracy, when socialism appears to be the maximin solution? Rawls does not attend to the set of facts about humans' natural-material existence when constructing his set of principles. His theory thus poorly approximates the requirements for human action and development.

The normative necessity that private persons and public citizens should be unified within society underpins Cohen's intuitionist method. The generation of our norms is not our social

\footnotetext{
${ }^{18}$ There is the possibility that extends beyond the theories of Marx, Rawls, and Cohen, which is that humans have evolved to have an innate desire to live. This would be a fact that we could base the $X P$ principles upon.
} 
agreement. Rather, our intuitive normative principles structure what our social agreement must address for the entirety of human personality to be supported. I would say that a materialist grounding of our social organization does the same thing while being fact-sensitive. Private persons and public citizens have the same natural-material basis. Their basis, as social contract theory presupposes, is not their abstract existence as rational choosers.

\section{Conclusion}

Cohen has shown that Rawls can't have inequality in the application of the difference principle when the parties of the original position favor egalitarianism as a starting point. But, capitalism precludes this critique by being an inhospitable ground for egalitarianism to take root. Even with this limitation I am curious to see if his critique will effect a reappraisal of the liberal political conception of justice that takes the enjoyment of basic liberties as primary (Rawls, 1993, 6).

Rawls spends much time trying to demonstrate that these basic liberties will not be upset by the inequalities of the difference principle (Rawls, 1993, 324-331). The most important reason for this is to forestall the development of reasonable envy that will prevent a society from having a sense of justice (Rawls, 1999, 468-470). Simply put, economic inequalities prevent people from seeing participation in their society as a good. People will feel their society is unjust if the foundational notions they accept as fair go unfulfilled. As Cohen demonstrates, the liberal conception of justice, which prizes the enjoyment of basic liberties, fails in its facilitation because of the contradictory sanctioning of inegalitarian incentives.

Even though Cohen is successful, he misses the weakest link in liberalism, at least in Rescuing, which is its neglect of human natural-material existence being disrupted by the dynamics of capital accumulation. Only when human's natural-material needs cannot be 
alienated can we meaningfully have the unity of public and private selves that Cohen wishes to follow from Marx's analysis in On the Jewish Question. Interestingly, a second theme Marx considers, which Cohen does not discuss in Rescuing, is the merely formal nature of the liberal conception of basic liberties (Marx, 1975, 229). The public and private division and merely formal liberties are interrelated problems. Cohen doesn't consider why liberties are intrinsically formal for liberal political theory. The superstructural presentation of liberties will be in conformity with the economic base of a mode of production (as Cohen himself discusses it in Cohen, 2000, 232). The liberal conception of rights facilitates capital accumulation. Freedom will only be the freedom to own property as long as civilization's is organized to serve the requirements of capital accumulation and not human need. If we wish to correct the liberal division between public and private selves the merely formal conception of liberties must be corrected also. One cannot live up to the ideals of our society if social dynamics are contrary to these ideals. The flaw in the egalitarianism of Rawls is due to capitalism's inability to accommodate humans as natural-material beings and not mere fictions. Cohen's critique of Rawls' inconsistency misses what has caused it.

\section{Works Cited}

Aristotle. 1984. Aristotle's Nicomachean Ethics. Translated by Hippocrates G. Apostle. Grinnell, Iowa: The Peripatetic Press.

Cohen, G.A. 1995. Self-Ownership, Freedom and Equality. Cambridge: Cambridge University Press.

Cohen, G.A. 2000. Karl Marx's Theory of History: A Defense. Expanded Edition. Princeton, New Jersey: Princeton, University Press. 
Cohen, G.A. 2008. Rescuing Justice and Equality. Cambridge, Massachusetts and London, England: Harvard University Press.

Daniels, Norman. n.d. "Equal Liberty and Unequal Worth of Liberty." in Reading Rawls: Critical Studies of A Theory of Justice. Edited by Norman Daniels. New York: Basic Books.

Dworkin, Ronald. 1981. "What is Equality? Part 2: Equality of Resources." in Philosophy and Public Affairs, 10.

Esping-Andersen, Gosta. 1990. The Three Worlds of Welfare Capitalism. Princeton, New Jersey: Princeton University Press.

Gomberg, Paul. 2007. How to Make Opportunity Equal: Race and Contributive Justice. Malden, Massachusetts: Blackwell Publishing.

Habermas, Jürgen. 1995. "'Reconciliation Through the Public Use of Reason: Remarks on John Rawls' Political Liberalism.” in Journal of Philosophy, No. 92.

Hart, H.L.A. 1973. "Rawls on Liberty and its Priority." in University of Chicago Law Review, Vol. 40, No. 3.

Herrera, Rémy. 2006. "Three Movements of the French Revolt.” in Monthly Review, Vol. 58 No. 2.

Hobbes, Thomas. 1994. Leviathan. Indianapolis: Hackett Publishing Company.

Holt, Justin P. 2009a. Karl Marx's Philosophy of Nature, Action, and Society: A New Analysis. Newcastle upon Tyne: Cambridge Scholars Publishing.

Holt, Justin P. 2009b. "The Choice of Economic Systems in the Rawlsian Original Position." Paper presented at the Rethinking Marxism Conference in Amherst, Massachusetts.

Locke, John. 2003. Two Treatises of Government and A Letter Concerning Toleration. New Haven and London: Yale University Press.

Marx, Karl. 1973. Grundrisse. Translated by Martin Nicolaus. New York: Penguin Books.

Marx Karl. 1976. Capital. Volume 1. Translated by Ben Fowkes. New York: Penguin Books.

Marx, Karl and Frederick Engels. 1976. Karl Marx and Frederick Engels Collected Works, Volume 5. New York: International Publishers.

Miller, Richard. 1974. "Rawls and Marxism." in Philosophy and Public Affairs, Vol. 3, No. 2.

Nagel, Thomas. 1973. "Rawls on Justice." in Philosophical Review, Vol. LXXXII, No. 2. 
Nozick, Robert. 1974. Anarchy, State, and Utopia. United States: Basic Books.

Rawls, John. 1993. Political Liberalism. New York, Columbia University Press.

Rawls, John. 1999. A Theory of Justice, Revised Edition. Cambridge, Massachusetts: Harvard University Press.

Sandel, Michael. 1982, 1998. Liberalism and the Limits of Justice. Cambridge: Cambridge University Press.

Sen, Amartya. 1980. "Equality of What?" in Tanner Lecturse on Human Values, I, edited by M.S. McMurrin, Salt Lake City: University of Utah Press and Cambridge: Cambridge University Press.

Sen, Amartya. 1992. Inequality Reexamined. Cambridge, Massachusetts: Harvard University Press.

Sen, Amartya. 1999. Development as Freedom. New York: Anchor Books.

Stephens, John D. 1996. "Scandinavian Welfare States: Achievements, Crisis, and Prospects" in Welfare States in Transition: National Adaptations in Global Economies, edited by EspingAndersen. London: Sage Publications.

Walzer, Michael. 1983, Spheres of Justice: A Defense of Pluralism and Equality. United States: Basic Books. 